\author{
Michaela Sugrova, \\ Marketing and Trade Department, \\ Slovak University of Agriculture, \\ Nitra, Slovak Republic \\ Ludmila Nagyova, \\ Ph.D., Professor, Marketing and Trade Department, \\ Slovak University of Agriculture, \\ Nitra, Slovak Republic \\ Nada Hazuchova, \\ Ph.D., Marketing and Trade Department, \\ Mendel University in Brno \\ Brno, Czech Republic \\ Jana Stavkova, \\ Ph.D., Professor, Marketing and Trade Department, \\ Mendel University in Brno, \\ Brno, Czech Republic
}

\title{
CONSUMER BEHAVIOUR AT ALCOHOLIC BEVERAGES MARKETS OF CZECH REPUBLIC AND SLOVAKIA: TARGETING CONSUMER SEGMENTS
}

Constantly increasing consumption of alcohol and the associated negative consequences affecting human health and not only, present a major problem for Czech Republic, Slovakia and the world overall. Increased alcohol consumption is directly related to easier accessibility of alcoholic beverages, this especially concerns younger generation of consumers. It is generally known that one of the most frequent causes of premature death within the European Union is excessive consumption of alcoholic beverages. In terms of the consumed alcohol volumes, Czech Republic and Slovakia are among the countries with the highest levels of consumption in Europe. For this reason, the main purpose of this paper was to examine the consumption of alcohol and consumer behavior at the alcoholic beverages market using a marketing survey, and also to identify the main reasons leading to the consumption of alcoholic beverages, as well as the factors influencing the most on the consumer decision-making leading to purchases and consumption of alcohol in Czech Republic and Slovakia. Primary data was acquired through the questionnaire survey with 686 respondents in Slovakia and 757 respondents in Czech Republic. Based on the results of the questionnaire survey, it is possible to state that in both countries the most preferred alcoholic beverage is wine and the main motives behind the consumption of the consume preferred alcoholic drink are consumption during social events and entertainment as well as the fact that consumers just like its taste. The main reasons for consuming alcoholic beverages in both countries is the taste, while quality is considered to be the most important factor when deciding to buy a particular drink. Using the cluster analysis method, 5 segments were established and described for Czech Republic and Slovakia. Individual segments differ in their respective characteristics of consumer behavior in both countries.

Keywords: alcoholic beverages, alcohol consumption, consumer behaviour, consumer segments, Slovak Republic, Czech Republic.

Introduction. The anti-alcohol movement, which at first started gaining some importance in the past century, after some time gradually declined, becoming almost insignificant at the end of the twentieth century. This development reflects also the current situation, when the European Union is the region with 
the highest alcohol consumption in the world (Anderson, Baumberg, 2006). Average alcohol consumption across the $18 \mathrm{EU}$ member states for which statistics were available was approximately 10.6 liters of pure alcohol per adult (over 15 years old) as of 2012 (OECD, 2015). Over the last three decades, alcohol consumption has fallen in some of the EU member states, but has risen in others. In recent years, alcoholrelated drinking habits have been changing, with alcohol-related convergence among the member states playing an important role in this process. For example, we can observe now increased wine consumption in the countries where drinking beer is traditional and vice versa (OECD, 2012). Changes in alcohol consumption between countries over time are due not only to changes in alcohol drinking habits, but also due to state policy measures imposed to control alcohol consumption. In particular, advertising restrictions, sales control and taxation prove to be effective tools in reducing the level of alcohol consumption (Bennett, 2003 in OECD, 2012; WHO Europe, 2012 in OECD, 2012).

Czech Republic is at the forefront of European countries in terms of alcohol consumption. As compared to the European Union in general, in 2012 Czech Republic exceeded the average consumption across the member states by approximately 1 liter of pure alcohol per adult. Alcohol consumption in Czech Republic as of 2014 amounted to about 11.9 liters of pure alcohol per person older than 15 years (OECD, 2016). The Czech Statistical Office (2017) reports statistics on the consumption of alcohol per capita, including children and persons under 15. According to the 2016, consumption of pure alcohol per capita was 9.9 liters.

By the volume of alcohol consumption, Slovakia is rated similarly toCzech Republic, that is, at the top places within the European Union. According to the OECD (2016), in 2014, alcohol consumption in Slovakia amounted to approximately 10.1 liters of pure alcohol per person over 15 years of age. According to the Slovak Statistical Office (2017) in 2016, consumption of pure alcohol per capita was 8.3 liters.

Own attitude to the subject matter:

Given the ever-increasing alcohol consumption, especially among the younger generation, it is imperative to address this subject matter and bring more attention to this problem. It is necessary to identify the actual motives leading to alcohol consumption. In order to achieve successful demarketing, it is essential to focus on specific segments to make it really effective. For this reason, cluster analysis has been applied in this research.

Literature background. Consumer behaviour is constantly changing and for that reason is still the subject of several studies. Comprehensive knowledge of consumer behavior for marketing management is an important source of information for formulating marketing strategies. (Nagyová et al., 2012). The basis of the study of consumer behavior is knowing how it responds to various incentives and what influences its decision to buy the selected product. Consumer is in the decision-making process influenced by many factors - cultural, social, personal and psychological. (Horská et al., 2009). The assessment of the standard of living of the population and its development is affected by several indicators. The key indicators that allow assessment of the living standard and its development are the monetary income, consumption and food expenditures, housing, education etc. Data on the household incomes and expenditures for the stated needs point at the standard of living of the population as well as various social groups. Important is also the reciprocal comparison of the differences in expenditures for the basic living needs of the household (Kubicová - Kádeková, 2011). Regarding alcohol, several studies show that a significant factor influencing the attitudes and expectations of young people, as well as adults, is alcohol advertising and marketing (Johns Hopkins Bloomberg School of Public Health, 2007). According to Slováčková et al. (2016) alcohol consumption is influenced by several factors. In addition to legislation, alcohol consumption is also affected by the family, peers, personal characteristics, life experiences, moral values, socio-cultural factors, situational specifics, structural factors, advertising, marketing, media and local climate. Alcohol consumption has a significant positive, as well as the negative impact, on the physical, psychological and mental health of each of us (Moore et al., 2005). According to Egea et al. 
(2016), drinking alcohol is an occasional activity shared by people, often associated with festivals or other special occasions. Lopez - Cisneros et al. (2013) state that alcohol consumption is a global phenomenon that involves multiple factors and determinants. Generally speaking, alcohol is a legal food commodity. Alcohol consumption in Slovakia is more than a few centuries old tradition and is tolerated in society (Holienčinová, 2013). The Czech Republic is known for its long tradition in the production and consumption of beer and the beer industry is an important part of their culture (Dzúrová et al., 2010). The term alcoholic beverage includes drinks like a beer, wine and spirits. Based on the data from WHO, worldwide total per capita consumption of pure alcohol is $13.5 \mathrm{~g}$ per day. The spirits represent $50.1 \%$ of total alcoholic beverages consumption, followed by beer $(34.8 \%$ ) and wine $(8.0 \%)$ (Zhou, 2016). The structure of alcoholic beverages consumption is different in various countries and depends on the habits, customs and cultural traditions of population (Solov'ev, 2016). In contrast to the descending curve of wine consumption can be highlighted the increase in beer and spirits consumption driven mainly by the younger generations (Marinelli et al., 2014). Based on the other research findings, the traditional Italian drinking model is highly characterised by daily consumption of alcoholic beverages, mainly wine during meals. Alcohol such as wine is related to the Catholic tradition in this country and to the cycle of the cultivation (Guidi - Di Placido, 2015). There is a generally accepted viewpoint that the wine industry necesarilly needs to increase the quantity of wine consumers (Mcintyre et al., 2016). In general, in most European countries, the legal drinking age is 18, in Germany, the Netherlands, Belgium and Switzerland, it is 16 for wine and beer and 18 for strong alcoholic beverages. In Luxembourg, Portugal, and Spain, it is 16 for all alcoholic beverages and in Malta and Cyprus, it is 17 for all alcoholic beverages. In Iceland, it is 20 for all alcoholic beverages (WHO, 2013). Alcohol consumption by young people before the recommended age is the global problem. (Rowland, 2015). Harmful consequences of alcohol consumption are obvious, but nowadays most people of young generation have easy access to alcoholic beverages. Those alcoholic beverages are considered a potential source of pleasure and therefore should be regulate the marketing of alcoholic beverages (Sancho et al., 2011; Stautz - Marteau, 2016). In addition to differences in alcohol consumption among younger and older consumers, we can also see evident differences between genders in relation to alcohol consumption at various locations. Alcohol consumption is more common in men than in women. Several studies have found out that these differences are not significant in the population of the young adults, especially regarding to heavy episodic drinking. The prevalence of heavy episodic drinking is similar in men as well as in women (Moure - Rodríguez et al., 2016). Based on study by Raciti et al. (2013), women are less likely to consume alcohol in pubs compared to men. Women generally prefer to drink alcoholic beverages in restaurants or at friends' and family's households. Younger, as well as urban women incline to drink alcohol beverages in more public locations, for example: pubs, hotels and restaurants compared to older and rural women. According to Mwinilanaa Tampah et al. (2015) there are studies in which is recommended the daily consumption of alcoholic beverages. However, there are also studies where alcohol consumption has been ranked among the riskiest health factors. Rada - Ispas (2016) state that alcohol consumption negatively affects not only our health. Therefore, prevention and limitation are most important in reducing alcohol consumption. By Leasure (2015) lower consumption of alcohol does not represent an improvement in our health status. A variety of factors have been identified at the individual and the societal level, which affect the levels and patterns of alcohol consumption and the magnitude of alcohol-related problems in populations. Environmental factors include economic development, culture, availability of alcohol, and the comprehensiveness and levels of implementation and enforcement of alcohol policies. For a given level or pattern of drinking, vulnerabilities within a society are likely to have similar differential effects as those between societies. Although there is no single risk factor that is dominant, the more vulnerabilities a person has, the more likely the person is to develop alcohol-related problems as a result of alcohol consumption (WHO, 2015). Moreover, we can state, it is absolutely necessary to examine alcohol consumption, what are the main motives for drinking and what is the impact 
of alcohol consumption on the society.

Data and Methodology. The main objective of this paper was to examine the consumption of alcohol and consumer behaviour in the alcoholic beverages market using a marketing survey, also to identify the main reasons leading to the consumption of alcoholic beverages, as well as the factors most influencing consumer decision-making leading to the purchase and consumption of alcohol in the Czech Republic and Slovakia. The main source of primary data were the results of a questionnaire survey conducted in 2016 across Slovakia (686 respondents) and the Czech Republic (757 respondents). The survey results from both countries were then compared to each other. The structure of the surveyed sample group in Slovakia and the Czech Republic is presented in Table 1.

Table 1 - Structure of the surveyed sample group in SVK and CZE (based on Own processing, 2017)

\begin{tabular}{|c|c|c|c|}
\hline \multicolumn{2}{|r|}{ Factors/Groups } & $\begin{array}{l}\text { CZE } \\
(\%)\end{array}$ & $\begin{array}{l}\text { SVK } \\
(\%)\end{array}$ \\
\hline \multirow{2}{*}{ SEX } & men & 44,0 & 62,0 \\
\hline & women & 55,0 & 37,0 \\
\hline \multirow{4}{*}{ AGE } & $18-24$ years old & 66,0 & 59,0 \\
\hline & $25-39$ years old & 25,0 & 33,0 \\
\hline & $40-54$ years old & 6,0 & 5,0 \\
\hline & 55 years old and over & 2,0 & 1,0 \\
\hline \multirow{4}{*}{ Education } & primary & 1,0 & 1,0 \\
\hline & secondary & 2,0 & 2,0 \\
\hline & upper secondary with graduation exams & 54,0 & 46,0 \\
\hline & tertiary, university & 42,0 & 51,0 \\
\hline \multirow{5}{*}{$\begin{array}{l}\text { Current economic } \\
\text { activity }\end{array}$} & employee & 29,0 & 35,0 \\
\hline & self-employed person & 5,0 & 5,0 \\
\hline & student & 64,0 & 55,0 \\
\hline & retired & 1,0 & 1,0 \\
\hline & unemployed & 1,0 & 4,0 \\
\hline \multirow{5}{*}{ Monthly income } & up to $10000 \mathrm{CZK} / 370$ Euro & 56,0 & 50,0 \\
\hline & $10001-20000$ CZK /371 - 740 Euro & 21,0 & 24,0 \\
\hline & 20001 - 30000 CZK /741 - 1100 Euro & 12,0 & 16,0 \\
\hline & $30001-40000$ CZK /1101 - 1500 Euro & 7,0 & 5,0 \\
\hline & 40001 or more CZK /1501 or more Euro & 4,0 & 4,0 \\
\hline \multirow{5}{*}{ Residing city size } & up to 2000 residents & 22,0 & 27,0 \\
\hline & $2001-5000$ residents & 10,0 & 21,0 \\
\hline & $5001-20000$ residents & 12,0 & 14,0 \\
\hline & $20001-50000$ residents & 15,0 & 15,0 \\
\hline & 50001 or more residents & 40,0 & 23,0 \\
\hline
\end{tabular}

The questionnaire contained questions about the types and quantities of alcoholic beverages consumed, the reasons that lead to the consumption of alcoholic beverages, and the factors that are influencing the consumer in the alcoholic beverage market the most. From the results of the survey conducted in the Czech Republic and Slovakia, it is possible to describe Czech and Slovak consumers 
aged 18-24 with secondary or tertiary education who are employees or students with monthly income per capita up to 10,000 CZK (370 Euro) from the point of view of their behavior in the alcoholic beverages market.

Cluster analysis. When searching for similarities in consumer behaviour we used cluster analysis method. Application of cluster analysis is particularly suitable where there occurs a tendency to create natural clusters. The principle of clustering methods is to use a measure of dissimilarity (or similarity) of objects and clusters. The most widely used measure of dissimilarity is the Euclidean distance. For the purpose of this paper hierarchical agglomerative clustering procedure was selected, using the method of Squared Euclidean, which is a way of assessing the distance or similarity between objects and Furthest Neighbor Method at which there is the tendency to form compact, but not too large clusters. Using the cluster analysis method, 5 segments were created and described for the Czech Republic and Slovakia.

Results. Figure 1 shows the consumption of alcohol in liters of pure alcohol per capita between years 2001 and 2016 in Slovakia and the Czech Republic. These data are derived from the consumption of all types of alcoholic beverages, including beer, wine and spirits. In the Czech Republic, per capita consumption of alcohol is higher than in Slovakia during all years under review. In both countries, the development of alcohol consumption is fluctuating. The highest alcohol consumption per capita in Slovakia was in 2008 (9.6 liters) and the lowest in 2003 (8.1 liters), the highest alcohol consumption per capita in the Czech Republic was in 2007 to 2009 (10.4 liters) and the lowest in 2004, 2010, 2011, 2013 and 2015 (9.8 I). For all the compared years, in the Czech Republic there's recorded higher alcohol consumption per capita by about 1 liter compared to Slovakia.

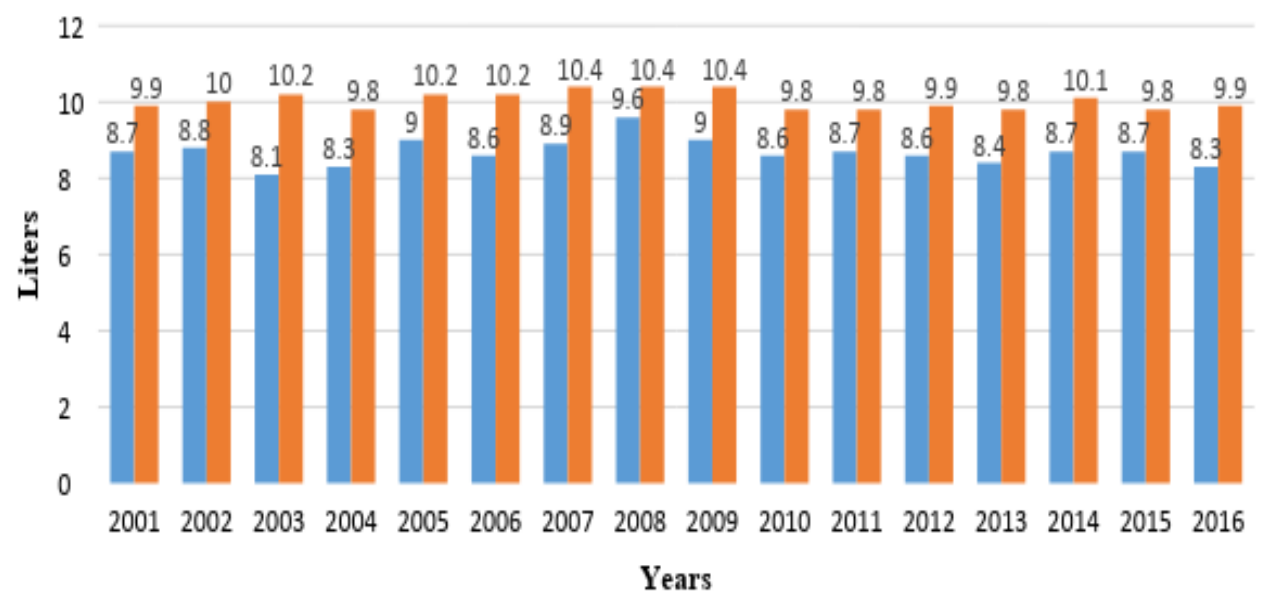

¿ Slovak Republic $\quad$ Czech Republic

Figure 1 - Alcohol consumption in liters of pure alcohol per capita between years 2001 - 2016 in

Slovakia and the Czech Republic (based on Statistical Office of the Slovak Republic and Czech

Statistical Office, own processing, 2017).

The results of the survey show that young people, mostly with secondary and tertiary education, prefer wine to beer as their choice of alcoholic beverage. This fact corresponds to the answers on the reasons that lead to consumption of the beverage, which mainly is its palatability. Wine is within this segment of the population more popular. Both countries coincide with liking the wine (figere 2-3). 
Which of the alcoholic beverages do you like the best (drink it most often)?

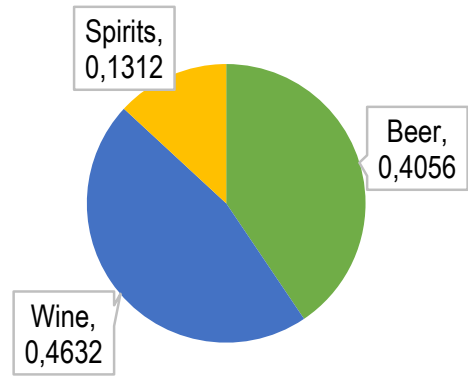

Figure 2 - Most commonly consumed alcoholic beverages in CZE (based on Own processing, 2017)
Which of the alcoholic beverages do you like the best (drink it most often)?

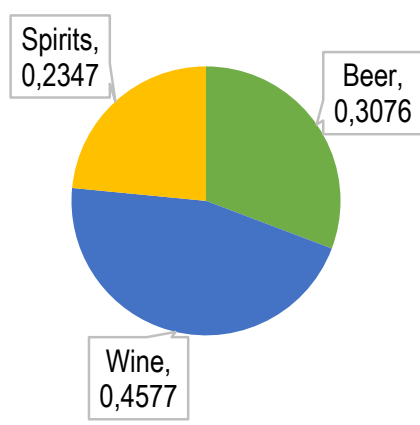

Figure 3 - Most commonly consumed alcoholic beverages in SVK (based on Own processing, 2017)

Most respondents, $57 \%$, as a reason for consuming chosen type of alcoholic beverage mention the taste properties of the drink, other reasons being easy accessibility and price ( $17 \%$ both reasons) and $10 \%$ named a habit (figure 4-5). These are serious findings useful for the combat with excessive alcohol consumption and consequences linked to alcohol abuse.

What are your reasons for drinking specifically this type of alcohol?
What are your reasons for drinking specifically this type of alcohol?

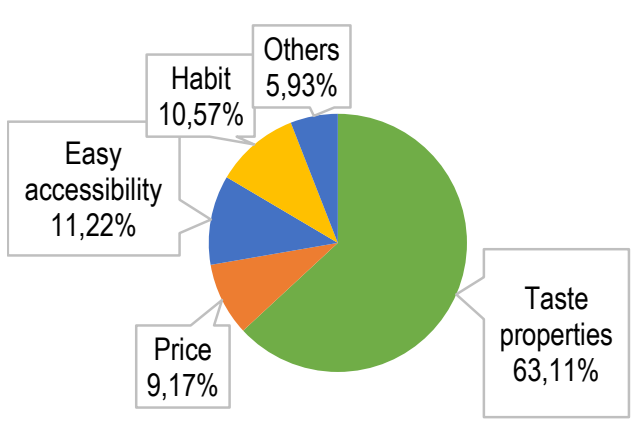

Figure 4 - Reasons for consumption of a given type of alcoholic beverage in CZE (based on Own processing, 2017)

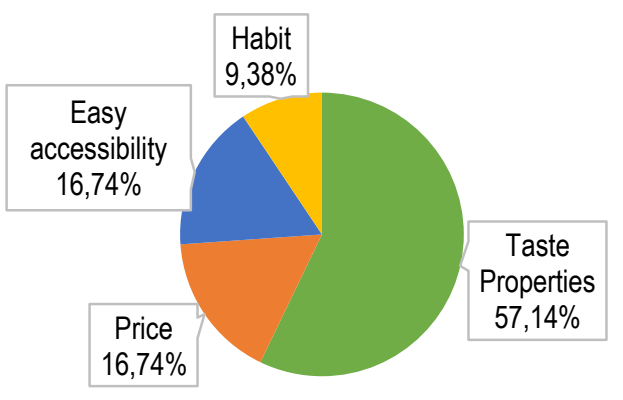

Figure 5 - Reasons for consumption of a given type of alcoholic beverage in SVK (based on Own processing, 2017)

Those people fighting with underage drinking should be advised, that for the large percentage of 
respondents, (which in subject classification are young people in that age when the habits are formed,) alcoholic beverages are easily accessible, both physically and financially. Equally significant finding is that in both countries around $10 \%$ of respondents admitted that they already have an alcohol drinking habit.

Frequency of consumption of individual types of alcoholic beverages is shown in Figure 6. Most respondents answered they drink occasionally or several times a week, same in Slovakia and in the Czech Republic. Daily consumption was admitted by less than $3 \%$ of respondents in both countries.

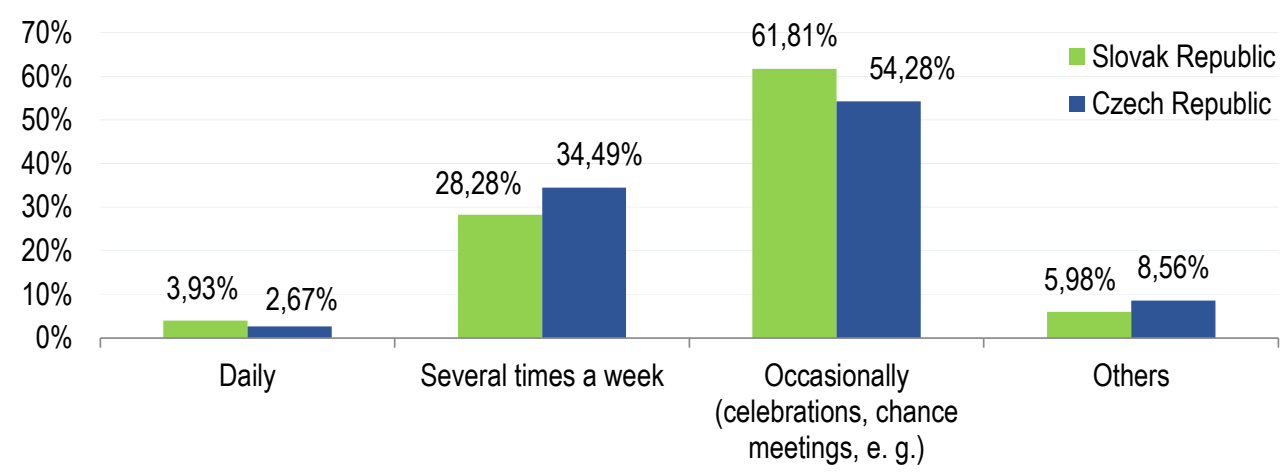

Figure 6-Frequency of consumption of individual types of alcoholic beverages in SVK and CZE (based on Own processing, 2017)

The situation is more favorable when looked upon the answers to questions that have quantitative nature, such as frequency, consumption in liters or CZK. Always the largest number of respondents is found at the lowest alternative. Two-thirds of respondents consume alcohol from zero to 1.5 liters per week, and this finding directly corresponds to expenses on alcohol from zero to $150 \mathrm{CZK} / 5.5$ Euro per week. However, both findings are not in line with quality factor, which by the views of respondents is most decisive factor when buying alcoholic beverages. Given the declared amounts of consumed alcoholic beverages and the money spent, quality cannot be accepted as the most important factor when purchasing alcoholic beverages.

The total amount of consumed alcoholic beverage per week was most frequently in the range 0-1.5 liters and in the range $1.5-3.0$ liters. Other consumption ranges seem constant (see Figure 7). Worthy of attention is the consumption of more than 6.0 liters per week, as well as less than $4 \%$ of respondents was not able to estimate the amount of alcohol consumed on average week.

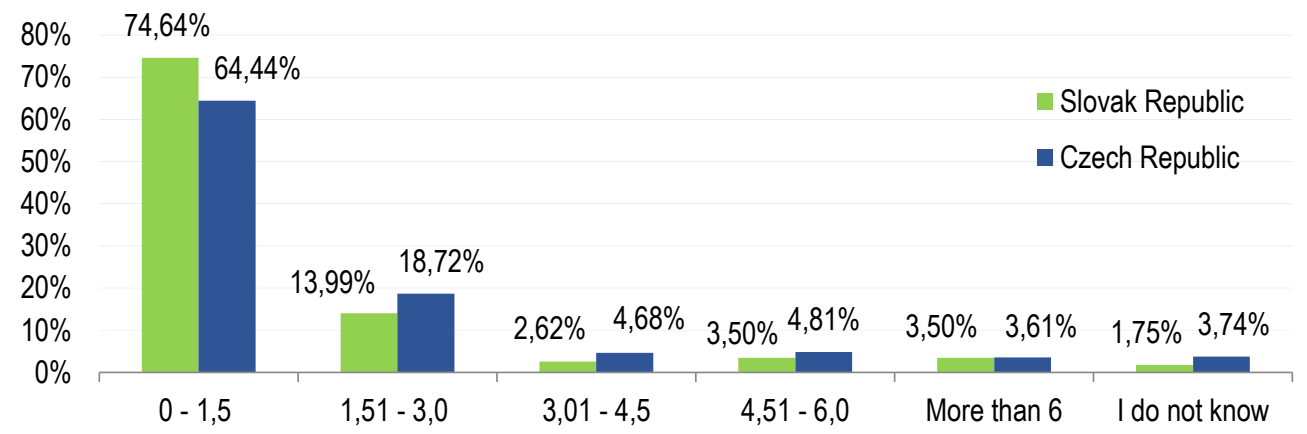

Figure 7 - Amount of consumed alcoholic beverage per capita per week in litters in SVK and CZE (based on Own processing, 2017) 
The weekly amount that respondents usually pay for the alcoholic beverages of the chosen type is for the majority of respondents in both the Czech Republic and Slovakia in the range of $150 \mathrm{CZK} / 5.5$ Euro, followed by $17 \%$ of respondents in Slovakia, $25 \%$ of respondents in the Czech Republic that usually pay between $151-300 \mathrm{CZK} / 5.51$ - 11.5 Euro and only for the few percent of respondents is the amount higher. $5 \%$ of respondents were not able to estimate the amoun (figure 8 ).

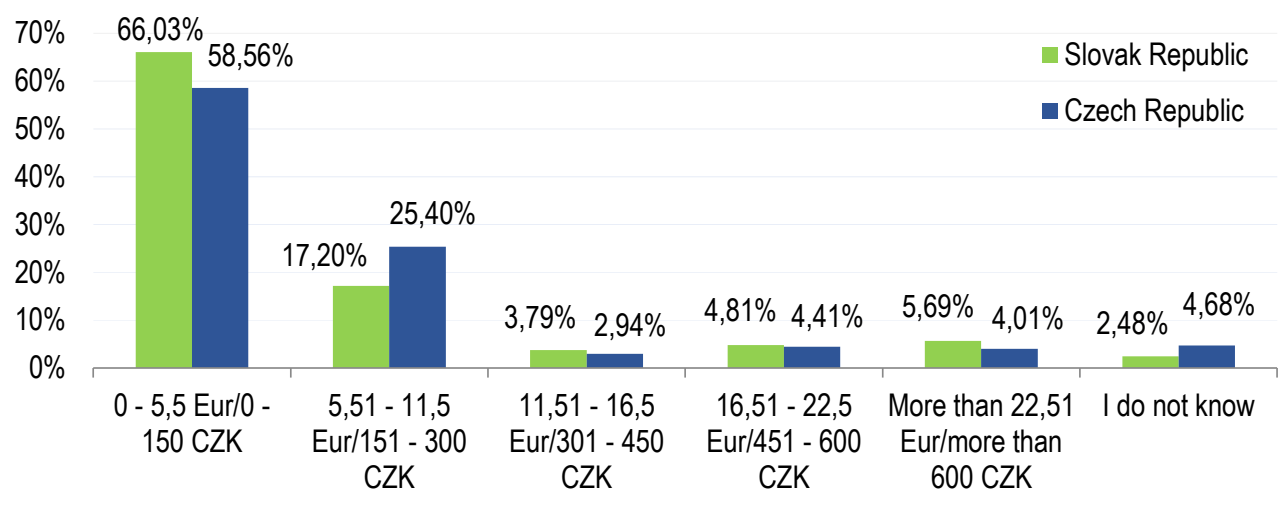

Figure 8 - The total expenses for consumed alcoholic beverages per capita per week in SVK and CZE (based on Own processing, 2017)

The place/situation where the respondents consume alcoholic beverages made the biggest difference between the two countries. Alcoholic beverages are consumed in Slovakia mainly in bars or pubs or on exceptional occasions, followed by home consumption. On the contrary, the smallest differences between the place of consumption of alcoholic beverages (see Figure 9) were recorded in Czech Republic (almost evenly distributed values).

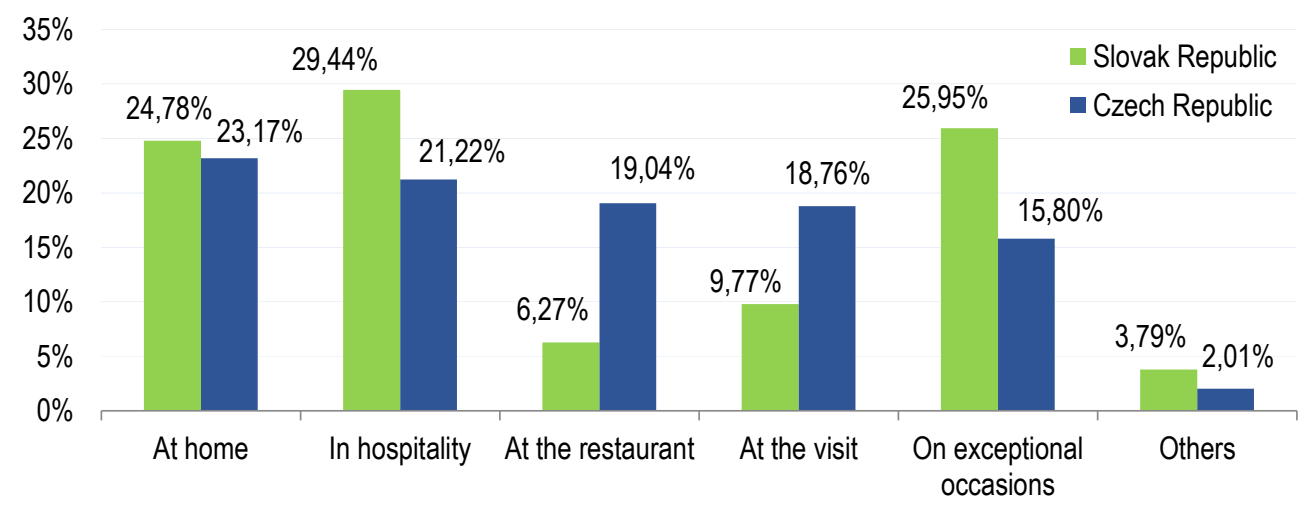

Figure 9 - Place of consumption of alcoholic beverages in SVK and CZE (based on Own processing, 2017)

Also interesting are the motives that lead the respondents to consume alcoholic beverages. The main reason to drink alcohol is the fact that it is tasty, equally numerous is the reason that consumption of alcoholic beverages happens during the entertainment activities, followed by drinking due the health 
effects and for relaxation, to satisfy thirst and then also to maintain the social status. Total numbers in both countries are close with two visible differences, one is the consumption of alcohol during the entertainment seems to have more importance in Slovakia, and in the Czech Republic maintaining social status is more relevant. The score representation is exhibited in Figure 10.

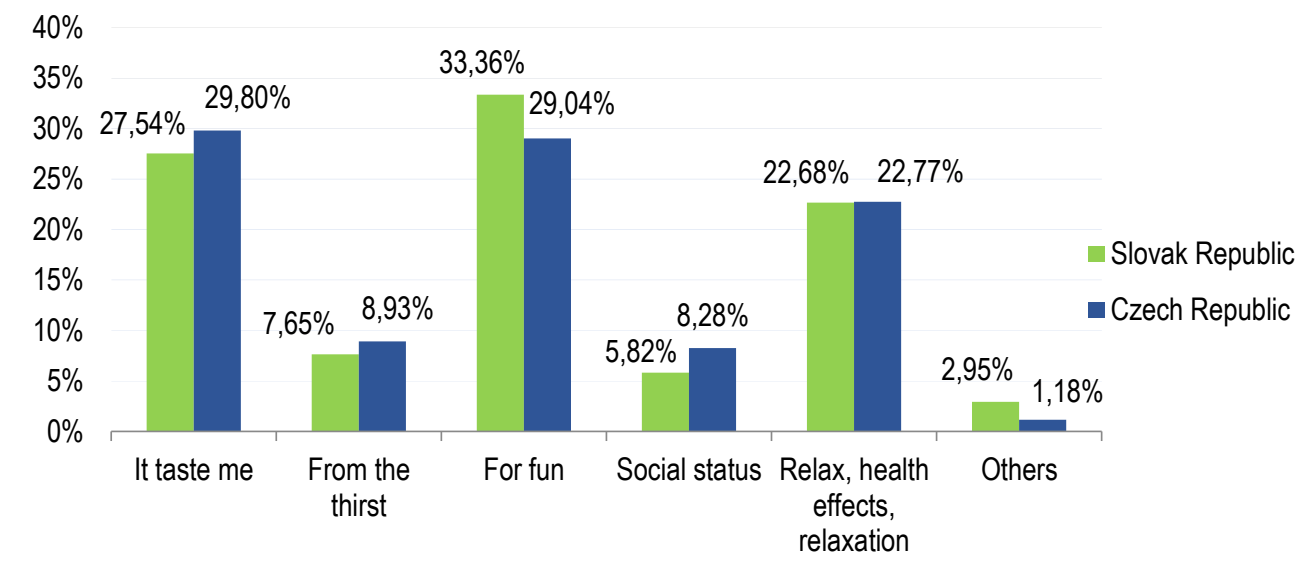

Figure 10 - Reasons for consumption of alcoholic beverages in SVK and CZE (based on Own processing, 2017)

During the search for factors that influence consumer behavior in the alcoholic beverage market the most, respondents expressed their opinion on the importance of the individual factors by the number of points allocated on the 10-point scale, with the following results: the greatest importance the respondents assigned to the product quality factor, then the recommendations, price, useful properties, brand, producer, discount offer (flyer), and product ad. These mentioned factors only influence the decisions about the choice of alcoholic beverage, not the consumption itself. These factors have a relation to quality, sometimes indirect (recommendations from friends) or directly to the brand and producer. The least significance for the purchase respondents admitted have advertising and discount events. The importance of the different purchasing factors in both countries is very similar. Emphasized importance of the quality does not correspond to the finding about the amount of consumed alcoholic beverages and the money spent on them. The money spent on admitted consumed amounts does not match the required high quality. Point representation of the significance of individual factors in the CZE and SVK is exhibited in Figure 11.

Knowing the individual factors that affect the purchase contributes not only to the improvements in theory of consumer behavior, but also to the use of appropriate marketing tools and anti-alcohol legislation in the context of alcohol consumption.

Targeting individual consumer segments created by cluster analysis method helped with increasing the efficiency while using marketing tools. Its application on CZE data resulted in creating 5 segments, which can be characterized as follows:

Segment 1. Segment can be characterized as a group that is not definitely set on the consumption of alcoholic beverages, and it cannot be branded for drinkers. If they consume, then occasionally, prefer wine, with minimal knowledge of the significance of the factors that motivate the consumption of the drink. This segment is predominantly made up of university students, with no opinion on the quality of alcoholic beverages, with a bit of exaggeration, the segment can be described as abstainers.

Segment 2. This segment prefers beer as the alcoholic beverage of the choice. The stated reason for 
consumption are the taste properties of the beer, decisive factors are quality, brand, manufacturer. Weekly consumption of this alcoholic beverage (beer) is the largest of all segments, up to 4 liters (excluding segment 1). Consumers of the 25-40 age group predominate, mostly employees, with secondary education. Beverage expenses are among the lowest - 200 CZK per week. The place for the consumption has 2 alternatives - at home or in the pub.

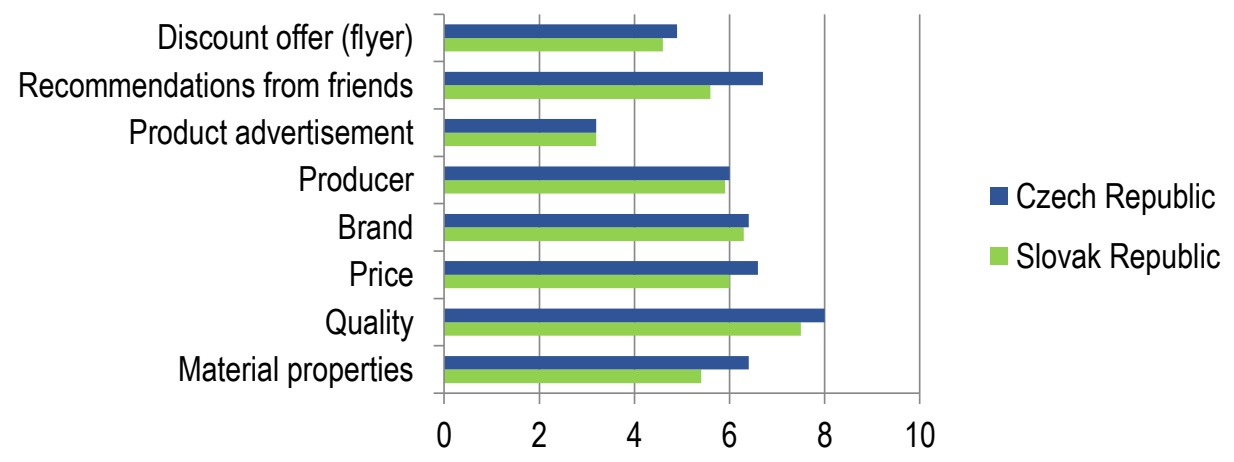

Figure 11 - Point representation of the significance of individual factors in SVK and CZE (based on Own processing, 2017)

Segment 3. Segment that prefers spirits, younger ages 18-24, predominantly secondary education, students. The decisive factor for buying and drinking is taste, price, various discount events and cost effective deals. This is a low-income segment, but weekly expenses of around $400 \mathrm{CZK}$.

Segment 4. Segments of spirits consumers, consuming occasionally, in restaurant facilities, quality selected brands, regardless of price. A segment achieving the highest monthly earnings, mostly with an economic activity as employee, with an emphasis on social status.

Segment 5. Segment of casual wine consumers, for its taste, properties and quality, which consumers associate with relaxation and stay in a nice environment. It consists of college students, monthly earnings up to 20,000 CZK, with an emphasis on social status.

Based on the survey results in Slovakia, using the method of cluster analysis, 5 segments were created too, but they distinguish from the Czech Republic segments:

Segment 1. This segment is made up of consumers of spirits, for which they decide due to the taste properties of the product. The consumer segment favors high quality, specific manufacturer and brand. Weekly consumption is about 1.5 liter, alcohol is consumed occasionally, with weekly expenses of about 150 CZK.

Segment 2. Segment can be branded as a segment of beer consumers. Decisive factor are clearly its taste properties, they consume beer on any occasion, they decide by quality, manufacturer and brand.

Segment 3. Segment of consumers who prefer wine before the rest of alcoholic beverages. Crucial is its taste and price, the consumption of wine has become a certain habit, this type of drink is consumed to satisfy thirst. Among the characteristics that motivate consumption, unlike the previous two segments, there is a lack of quality, and neither brand or producer play any significant role.

Segment 4.Segment that includes consumers with not definitive view on alcoholic beverages, with minimal consumption and minimal alcohol expenditures.

Segment 5. Includes consumers who prefer spirits but consume other alcohol too, they consume to satisfy thirst, search for cost-effective products, with certain utility properties.

Conclusion. The main purpose of this paper was to examine the alcohol consumption and to point out 
consumer behavior in the alcohol market, as well as the reasons leading to the consumption of alcoholic beverages and the factors most affecting consumers in the alcoholic beverages market. In order to meet the main objective, a questionnaire survey was carried out in Slovakia and Czech Republic and subsequently we used cluster analysis method. Our research served also to point out the ever-increasing consumption of alcoholic beverages in Slovakia and in the Czech Republic. Within the research, we used cluster analysis to create individual clusters and focused on them, to help with recognizing consumer behavior across the segments. The questionnaire survey showed that the most commonly consumed alcoholic beverage in Slovakia (45.77\%) and in the Czech Republic (46.32\%) is wine. The main reason for consumption of alcoholic beverages in both countries is their taste (SVK 63.11\% and CZE 57.14\%). From the anti-alcohol policy point of view, it is crucial to address the main reasons for the high alcohol consumption in both countries, which include easy alcohol availability and low price. The serious finding was that approximately $10 \%$ of respondents from both countries admit they have a drinking habit. Regarding the frequency of consumption of individual types of alcoholic beverages in Slovakia and in the Czech Republic, they are most often consumed occasionally - celebrations, occasional meetings, etc. (SVK - 61.81\% and CZE - 54.28\%). The total volume of alcohol consumed per week per capita moves in both countries mostly within the margins 0 and 1.5 liters (SVK 74.64\% and CZE 64.44\%). This corresponds to the amount of funds spent on alcoholic beverages per capita per week, in both countries it is 0 - 5.5 Euro / 0 - 150 CZK (SVK 66.03\% and CZE 58.56\%). The biggest differences found concerned the place where consumption of alcoholic beverages happens. While bars and pubs prevail in Slovakia (29.44\%), alcohol consumption in the Czech Republic is greatest at home (23.17\%). Interesting are the reasons for consumption of alcoholic beverages, with approximately the same results recorded in both countries. In Slovakia, the main motive is the consumption of alcohol during the entertainment activities $(33.36 \%)$ and the fact that they taste good $(27.54 \%)$. In the Czech Republic, the main motive is the taste of the drink $(29.8 \%)$ and then follows entertainment (29.04\%). The most influential factors affecting consumers during the purchase of alcoholic beverages include quality, according to the point representation of selected factors in both regions. This finding, however, does not correspond to the volume of consumed alcoholic beverages and the funds spent, as the amount of money spent on the quantity of alcoholic beverages consumed does not correspond with high quality. Based on the results of the cluster analysis, 5 segments were created in both Slovakia and Czech Republic. There are proven differences between countries and individual segments. The first segment from the Czech Republic is a segment with not clearly defined opinion, consumes alcoholic beverages in a minimal amount, they are almost abstainers, university students, and if alcohol then it is only occasionally wine. The first segment from Slovakia is represented by consumers of spirits, alcohol is consumed occasionally, they decide according to the taste properties and prefer high quality, manufacturer and brand. The second segment from the Czech Republic clearly prefers beer, primarily due to its taste properties. The consumption per capita is highest - 4 liters per week; it is made up of consumers aged $25-40$ with secondary education. The second segment from Slovakia is a segment of beer consumers, it is consumed on any occasion and the taste properties are decisive. The third segment from the Czech Republic is represented by the age group of 18-24 years, especially students, low-income consumers who prefer spirits. In Slovakia, third segment represents consumers of wine. The taste properties are decisive, quality is insignificant, consumers have developed drinking habit and are consuming wine to satisfy their thirst. The fourth segment from the Czech Republic includes occasional drinkers of spirits. They prefer selected brands regardless of price, this segment has the highest revenue and a certain social status. The fourth segment from Slovakia is a segment without definite opinion on alcoholic beverages and with minimal consumption of alcohol. The fifth segment from the Czech Republic is a segment of occasional wine consumers (college students), mainly because of its taste and relaxation. The fifth segment from Slovakia is made up of spirit drinkers, who, however, consume also other alcohol, especially to satisfy their thirst. 
M. Sugrova, L. Nagyova, N. Hazuchova, J. Stavkova. Consumer Behaviour at the Alcoholic Beverages Market in the Czech Republic and Slovakia: Targeted on Individual Consumer Segments

Bennett, J. (2003). Investment in Population Health in Five OECD Countries. Retrieved April 10, 2018, from https://www.oecdilibrary.org/docserver/073776747532.pdf?

expires=1527499320\&id=id\&accname=guest\&checksum=F3FBA217DCD1F53A4DD82328E6D8F5EB .

Dzúrová, D., Spilková, J. \& Pikhart, H. (2010). Social inequalities in alcohol consumption in the Czech Republic: A multilevel analysis. Health \& Place, 16(3), 590-597. doi.org/10.1016/j.healthplace.2010.01.004.

Egea, T., Signorini, M. A., Ongaro, L., Rivera, D., Obón de Castro, C. \& Bruschi, P. (2016). Traditional alcoholic beverages and their value in the local culture of the Alta Valle del Reno, a mountain borderland between Tuscany and Emilia-Romagna (Italy). Journal of Ethnobiology and Ethnomedicine, 12, 27. doi.org/10.1186/s13002-016-0099-6.

Holienčinová, M. (2013). Spotrebitel'ské správanie na trhu alkoholických nápojov. Paper presented at the meeting of Faculty of Business Economics of the University of Economics in Bratislava with seat in Košice, Košice.

Horská, E., Nagyová, L., Stávková, J., Turčínková, J., Stejskal, L., Bolaños, R. M., Araque Padilla, R. A., Montero Simó, M. J., Ramírez Sobrino, J. N., Matysik-Pejas, R., Szafrańska, M. (2009). Európsky spotrebitel' a spotrebitel'ské správanie. Nitra: Slovenská pol'nohospodárska univerzita v Nitre.

Guidi, P. \& Di Placido, M. (2015). Social work assessment of underage alcohol consumption: Non-specialised social services comparison between Sweden and Italy. Nordic studies on alcohol and drugs, 32(2), 199-218. doi: 10.1515/nsad-2015-0020.

Johns Hopkins Bloomberg School of Public Health. (2007). Alcohol Advertising and Youth. Retrieved March 04, 2017, from http://www.camy.org/resources/fact-sheets/ alcohol-advertising-and-youth/.

Kubicová, L'. \& Kádeková, Z. (2011). Comparison of the income development and the food demand elasticities of the private households in Slovakia. Agricultural economics, 57(8), 404-411.

Leasure, J. L., Neighbors, C., Henderson, C. E. \& Young, Ch. M. (2015). Exercise and alcohol consumption: what we know, what we need to know, and why it is important. Frontiers in Psychiatry, 6: 156. doi.org/10.3389/fpsyt.2015.00156.

López Cisneros, M. A., Villar Luis, M. A., Alonso-Castillo, M. M., De Jesús Alonso Castillo, M. T. \& Aguilar, L. R. (2013). Attitudes towards consumption and non-consumption of alcohol among high school students in Mexico. Revista Da Escola De Enfermagem Da USP, 47(4), 815-820. doi:10.1590/S0080-623420130000400007.

Marinelli, N., Fabbrizzi, S., Alampi Sottini, V., Sacchelli, S., Bernetti, I., Menghini, S. (2014). Generation Y, winy and alcohol. A semantic differential approach to consumtion analysis in Tuscany. Appetite, 75, 117-127. doi.org/10.1016/j.appet. 2013.12.013.

McIntyre, E., Ovington, L. A., Saliba, A. J. \& Moran, C. C. (2016). Qualitative study of alcohol consumer who choose to avoid wine. Australian Journal of grape and wine research, 22: 2, 182-189. doi.org/10.1111/ajgw.12182.

Moore A. A., Gould, R., Reuben, D. B., Greendale, G. A., Carter, K., Zhou, K. \& Karlamangla, A. (2005). Longitudinal Patterns and Predictors of Alcohol Consumption in the United States. American Journal of Public Health, 95(3), 458-464. 10.2105/AJPH.2003.019471

Moure-Rodríguez, L., Piñeiro, M., Corral Varela, M., Rodríguez-Holguín, S., Cadaveira, F. \& Caamaño-Isorna, F. (2016) Identifying Predictors and Prevalence of Alcohol Consumption among University Students: Nine Years of Follow-Up. PLOS ONE, 11(11). doi.org/10.1371/journal.pone.0165514.

Mwinilanaa Tampah-Naah, A. \& Twumasi Amoah, S. (2015). Consumption and drinking frequency of alcoholic beverage among women in Ghana: a cross-sectional study. BMC Public Health, 15: 317. doi.org/10.1186/s12889-015-1651-3.

Nagyová, L'., Horská, E., Paluchová, J., Kleinová, K., Kádeková, Z. \& Récky, R. (2012). Trendy v spotrebitel'skom správaní na trhu potravinárskych produktov v SR. Nitra: Slovenská pol'nohospodárska univerzita v Nitre.

OECD (2012). Health at a Glance: Europe 2012. Retrieved August 18, 2015.

OECD (2015). Tackling Harmful Alcohol Use: Economics and Public Health Policy. Retrieved August 18, 2015, from http://dx.doi.org/101787/9789 26418069-en.

OECD. (2016). Non - Medical Determinants of Health: Alcohol Consumption in Slovakia and Czech Republic. Retrieved February 10, 2017, from https://stats.oecd. org/index.aspx?DataSetCode=HEALTH_STAT.

Raciti, M., O'Hara, R., Sharma, B., Reinhard, K. \& Davis, F. (2013). Examining price promotions, venue and place of residence as predictors of alcohol consumption. Journal of Social Marketing, 3(1), 8-27. doi.org/10.1108/20426761311297207.

Rada, C. \& Ispas, A. T. (2016). Alcohol consumption and accentuated personality traits among young adults in Romania: a cross-sectional study. Substance Abuse Treatment, Prevention and Policy, 11(1): 36, doi:10.1186/s13011-016-0080-3.

Rowland, B., Evans-Whipp, T., Hemphill, S., Leung, R., Livingston, M. \& Toumbourou, J. W. (2016). The density of alcohol outlets and adolescent alcohol consumtion: An Australian longitudinal analysis. Health \& Place, 37, 43-49.

Sancho M. F., Miguel, M. J. \& Aldás, J. (2011). Factors influencing youth alcohol consumption intention. An approach from consumer socialization theory. Journal of Social Marketing, 1(3), 192-210. doi.org/10.1108/20426761111170704.

Slováčková, T., Birčiaková, N. \& Stávková, J. (2016). Forecasting alcohol consumption in the Czech Republic. Acta Universitatis Agriculturae et Silviculturae Mendelianae Brunensis, 64(6), 2133-2140. doi.org/10.1016/j.sbspro.2016.05.522.

Solov'ev, A. M. (2016). Comparative Rate of Alcohol Consumption in European Coutries. Studies on Russian Economic Development, 27(1): 94 doi.org/10.1134/S 1075700716010135.

Stautz, K. \& Marteau, T. M. (2016). Viewing alcohol warning advertising reduces urges to drink in young adults: an online experiment. BMC Public Health, 16(1), 530-540. doi.org/10.1186/s12889-016-3192-9.

The Czech Statistical Office. (2017). Spotřeba potravin - 2015: Spotřeba alkoholických nápojů a cigaret (na obyvatele za rok). Retrieved March 07, 2017, from https://www.czso.cz/. 
The Slovak Statistical Office. (2017). Spotreba vybraných druhov potravín na 1 obyvatela. Retrieved February 21, 2017, from https://slovak.statistics.sk.

WHO. (2015). Alcohol. Retrieved March 03, 2017, from http://www.who.int/media centre/factsheets/fs349/en/.

WHO. (2013). Status Report on Alcohol and Health in 35 European Countries 2013. Retrieved March 07, 2017, from http://www.euro.who.int/_data/assets/pdf_file/0017/ 190430/Status-Report-on-Alcohol-and-Health-in-35-European-Countries.pdf.

Zhou, Y., Zheng, J., Li, S., Zhou, T., Zhang, P. \& Li, H-B. (2016). Alcoholic Beverage Consumption and Chronic Diseases. International Journal of environmental research and public health, 13(6): 522. doi:10.3390/ijerph13060522.

М. Сугрова, Словацький університет сільського господарства (Нітра, Словаччина);

Л. Надьова, Ph.D., професор, Словацький університет сільського господарства (Нітра, Словаччина);

Н. Хазухова, Ph.D., Університет Менделя у Брно (Брно, Чехія);

Я. Ставкова, Ph.D., профресор, Університет Менделя у Брно (Брно, Чехія).

Поведінка споживачів на ринку алкогольної продукції Чехії та Словаччини: сегментування споживачів

Постійно зростаюче споживання алкоголю та пов'язані з ним негативні наслідки, що впливають на здоров'я людини, представляють серйозну проблему не тільки для Чехії й Словаччини, а й для всього світу в цілому. Збільшення споживання алкоголю, особливо серед молодого покоління, прямо пов'язане з його доступністю на ринку напоїв. Аналіз наукової літератури засвідчив, що однією з найбільш поширених причин передчасної смерті в Європейському союзі є надмірне споживання алкогольних напоїв. Найвищий рівень споживання алкоголю в Чехії та Словаччини серед країн Європи підтверджує актуальність даного дослідження. Основною метою статтіє дослідження особливостей поведінки споживачів на ринку алкогольних напоїв. 3 метою виявлення основних причин та факторів впливу на прийняття рішень споживачів щодо вибору та споживання алкогольних напоїв в роботі використовується маркетингові опитування. У ході дослідження було про анкетовано 686 респондентів Словаччини та 757 респондентів Чехії. Результати опитування свідчать, що в обох країнах найпоширенішим алкогольним напоєм $є$ вино, а основними мотивами його споживання $\epsilon$ кількість проведених в країнах культурно-розважальних заходів, рекомендації друзів та смакові переваги товару. При цьому зазначається, що якість товару не $є$ визначальним фактором збільшення кількості споживання алкогольних напоїв. Щодо місия споживання, то респонденти Чехії споживають алкогольні напої переважно вдома, а Словаччини - у ході розважальних заходів та менше всього в ресторанах та пабах. На основі методу кластерного аналізу в статт виділено 5 сегментів споживачів алкогольних напоїв Чехії і Словаччини та описано їх основні характеристики. Визначен особливості поведінки споживачів для кожного з запропонованих сегментів.

Ключові слова: алкогольні напої, споживання алкоголю, поведінка споживачів, споживчі сегменти, Словаччина, Чехія.

http://mmi.fem.sumdu.edu.ua/en 